\title{
Uroczystości państwowe, wojskowe i religijne w Korpusie Ochrony Pogranicza na przykładzie 16 Batalionu „Sienkiewicze" w latach 1927-1932
}

Streszczenie. Artykuł opisuje obchody świąt kościelnych, wojskowych i państwowych w 16 batalionie Korpusu Ochrony Pogranicza w latach 1927-1932. Okres wskazany w tytule pokrywa się w czasie z dowodzeniem batalionu przez majora/podpułkownika Stanisława Hojnowskiego, oficera Wojska Polskiego, późniejszego dowódcy 45 pułku piechoty. W tekście omówiono sposoby obchodzenia: Wielkanocy, Bożego Narodzenia, Święta Żołnierza Polskiego, 11 listopada, imieniny Marszałka Piłsudskiego etc. w 16 Batalionie Korpusu Ochrony Pogranicza. Jako że święta te rokrocznie wyglądały podobnie, omówiono je na wybranych przykładach. Na Kresach Wschodnich, gdzie Polacy stanowili mniejszość, tego typu przedsięwzięcia, oprócz zabawy i wprowadzenia kolorytu w szare życie, pełniły ważną propagandową rolę. Scalały również ludność wschodnich połaci kraju z Polską.

Słowa kluczowe: Korpus Ochrony Pogranicza, 16 Batalion „Sienkiewicze”, Stanisław Hojnowski, 11 listopada, 15 sierpnia, Wielkanoc, Boże Narodzenie, imieniny Marszałka Piłsudskiego, historia Polesia, województwo poleskie.

$\mathrm{K}$ orpus Ochrony Pogranicza (KOP) ${ }^{1}$ powołany na mocy rozkazu z 12 września 1924 r., miał służyć na wschodniej granicy Rzeczypospolitej Polskiej. Korpus zajmował się jednak nie tylko ochroną granic, ale i działalnością kulturalno-oświatową polegającą m.in. na zwalczaniu analfabetyzmu i dokształcania żołnierzy, nie ograniczając się w sferze kulturalnej i propagandowej tylko do służących w KOP, lecz oddziaływał również na miejscową ludność.

Wspomnieć należy również, że po odzyskaniu przez Polskę niepodległości na Polesiu wobec słabej orientacji narodowej mieszkańców, rozpoczęto indoktrynację

* Wydział Filozoficzno-Historyczny, Studium Doktoranckie Nauk Humanistycznych, e-mail: lolomar@wp.pl.

${ }^{1}$ W tekście użyto następujących skrótów: DOK - Dowództwo Okręgu Korpusu, Dz. Pers. MSWojsk. - Dziennik Personalny Ministerstwa Spraw Wojskowych, Dz.U. - Dziennik Ustaw, KOP - Korpus Ochrony Pogranicza, PW - Przysposobienie Wojskowe. 
„tutejszych”, co znalazło odzwierciedlenie m.in. w szkolnictwie. Szkoły miały wychować dzieci i młodzież w polskim duchu narodowym. Młodych, bez względu np. na wyznawaną religię, uświadamiano w duchu polskości. W nauczaniu kładziono nacisk na dorobek kulturowy Polski, polską kulturę oraz wzbudzano szacunek do polskich bohaterów i podkreślano rolę Polski w podnoszeniu poziomu życia lokalnych mieszkańców ${ }^{2}$. Często taka postawa powodowała opór u uczniów i rodziców, co pociągało za sobą bojkot polskich szkół. Pewnym kompromisem było wprowadzenie w 1924 r. szkół, w których nauczano w języku miejscowym oraz polskim. Sytuacja zmieniła się po przewrocie majowym 1926 r., kiedy to częściowo odstąpiono od prowadzonej wcześniej polityki m.in. obiecując zwiększenie współuczestnictwa mniejszości w administracji państwowej. Planowano zwiększenie nacisku na zaspokojenie dążeń gospodarczo-kulturalnych, bez wprowadzenia faktycznej autonomii. Władze liczyły, że w ten sposób pozyskają miejscowych dla polskiej racji stanu. Lojalność państwowa miała przynieść korzyści obu stronom, mieszkańcy Polesia dzięki poprawie egzystencji czy poszanowaniu praw mniejszości mieli odwdzięczyć się wiernością wobec państwa. Zwolennikiem takiego działania był Jan Krahelski, wojewoda poleski w latach 1926-1932, który nie był jednak w stanie przeforsować tych rozwiązań w Warszawie. W miarę umacniania się władzy sanacji, coraz więcej sympatyków zyskiwała koncepcja regionalizmu, pozwalająca na stosowanie w zależności od regionu kraju rozwiązań indywidualnych ${ }^{3}$.

W okresie międzywojennym wszystkie formacje wojskowe urządzały obchody różnych świąt. Nie inaczej było również w KOP, jednak w tej formacji poszczególne uroczystości miały dodatkowy motyw w postaci krzewienia polskiej kultury na kresach zdominowanych przez ludność niepolską, zacieśniania z nią więzi oraz propagowania wartości uznawanych przez polskie władze. Ponadto święta organizowane lub współorganizowane przez KOP były swego rodzaju wydarzeniami kulturalnymi dla mieszkańców danej okolicy, w trakcie których mogli oni obejrzeć przedstawienie teatralne lub film. Wprowadzało to pewną dozę kolorytu w szare życie kresów.

Uroczystości organizowane bądź współorganizowane przez KOP (kościelne, narodowe i wojskowe) cieszyły się dużą popularnością wśród miejscowej ludności. Wiele z nich stawało się świętem całej lokalnej społeczności, która chętnie brała udział we wszystkich tych wydarzeniach ${ }^{4}$. W konsekwencji można mówić o masowym - choć zapewne nie zawsze w pełni dobrowolnym - uczestnictwie społeczności lokalnych w obchodach większości świąt współorganizowanych

2 W. Śles zyńs ski, Województwo poleskie, Kraków 2014, s. 204-208.

3 Ibidem, s. 280-281.

${ }^{4}$ Nasz dorobek pracy kulturalno-oświatowej, [w:] Korpus Ochrony Pogranicza. W trzecia rocznice objęcia stużby na granicach Rzeczypospolitej 1926-1927, red. F. Jamka-Koperski, Warszawa 1927, s. 14-16. 
przez KOP (państwowych, np. 3 maja czy kościelnych - Wielkanoc i Boże Narodzenie) oraz organizowanych przez KOP uroczystościach wojskowych i różnych rocznicach, jak np. imieniny Marszałka (19 marca) czy Święto Żołnierza Polskiego (15 sierpnia).

Same święta były również doskonałą okazją do zaprezentowania siły państwa polskiego. Niekiedy były one jedyną możliwością dotarcia do mieszkańców z przekazem propagandowym. Bierny udział ludności w uroczystościach nie wymagał zaangażowania z ich strony, jednak dawał im możliwość chwilowego oderwania od rzeczywistości. Władze państwowe, zdając sobie z tego sprawę, starannie się do takich uroczystości przygotowywały. W defiladach i manifestacjach udział brali nie tylko urzędnicy państwowi, policja, wojsko, lecz także organizacje społeczne, zwłaszcza te młodzieżowe. Przy okazji świąt narodowych w świątyniach celebrowano uroczyste nabożeństwa 5 .

Miejscowość Sienkiewicze - znajdująca się obecnie w granicach Białorusi - w okresie międzywojennym leżała w granicach II Rzeczypospolitej. Położona była w powiecie łuninieckim ${ }^{6}$ w województwie poleskim (do 1928 r. w gminie Lenin, następnie w gminie Łachwa7). W 1921 r. miejscowość liczyła 667 mieszkańców ${ }^{8}$. Pierwszy powszechny spis ludności z 1921 r. (który został przeprowadzony w specyficznych warunkach, na wschodnich terenach administracja polska dopiero się kształtowała, panowała epidemia tyfusu ${ }^{9}$ oraz trwały ruchy ludności etc.) wykazał, że powiat łuniniecki posiadał 179518 mieszkańców (w tym: katolicy 10576 osób i prawosławni 152044 osoby) ${ }^{10}$, zaś według danych drugiego spisu powszechnego, przeprowadzonego w 1931 r. powiat miał 108663 mieszkańców, z czego jako język ojczysty polski deklarowało 16535 osób, białoruski 2850 osób, zaś ,tutejszy” aż 80323 osób ${ }^{11}$. Jeśli chodzi o wyznanie, to na obszarze powiatu 13754 osób wskazało wyznanie rzymskokatolickie, natomiast 85643 prawosławie $^{12}$. Przewagę mieli prawosławni, więc działania kulturalno-oświatowe musiały kłaść nacisk na integrację miejscowej ludności z Polską.

5 Ibidem, s. 213.

${ }^{6}$ Skorowidz miejscowości Rzeczypospolitej Polskiej z oznaczeniem terytorjalnie im właściwych władz i urzędów oraz urządzeń komunikacyjnych, red. T. Bystrzycki, Przemyśl-Warszawa [b.d.w.], s. 1533.

7 Dz.U. 1928, nr 46, poz. 452.

${ }^{8}$ Skorowidz miejscowości Rzeczypospolitej Polskiej opracowany na podstawie wyników Pierwszego Powszechnego Spisu Ludności z dn. 30 września 1921 r. i innych źródet urzędowych, t. VIII (Województwo Poleskie), Warszawa 1924, s. 39.

9 Vide: A. R ze p k ow s ki, Spisy ludności na ziemiach polskich w latach 1789-1939, „Przegląd Nauk Historycznych" 2005, nr 2 (8), s. 117.

${ }_{10}$ Pierwszy powszechny spis Rzeczypospolitej Polskiej z dnia 30 września 1921 r. Mieszkania. Ludność. Stosunki zawodowe. Województwo poleskie, Warszawa 1926, s. 28-29.

${ }^{11}$ Drugi powszechny spis ludności z dn. 9.XII.1931 r. Mieszkania i gospodarstwa domowe. Ludność. Stosunki zawodowe. Województwo poleskie, Warszawa 1938, s. 26.

12 Ibidem, s. 24. 
Po powstaniu KOP - Sienkiewicze stały się siedzibą dowództwa 16 Batalionu Granicznego ${ }^{13}$. Został on sformowany przez 84 pułk piechoty ${ }^{14}$. W jego skład wchodziły 3 kompanie graniczne: „Pieszczaniki”, „Grabów” i „Lenin”. Sam batalion podlegał 5 Brygadzie KOP „Polesie” ${ }^{15}$. Celem artykułu jest przedstawienie obchodów świąt państwowych, wojskowych i religijnych we wspomnianym batalionie KOP w latach 1927-1932. Okres ten zbiega się z czasem, kiedy drugim z kolei dowódcą batalionu był mjr/ppłk Stanisław Piotr Hojnowski (1893-1939). Oficer ten trafił do KOP z 85 pułku piechoty, po czym w 1932 r. został przeniesiony na stanowisko zastępcy dowódcy w 15 pułku piechoty ${ }^{16}$. W trakcie służby w KOP otrzymał awans do stopnia podpułkownika z dniem 1 stycznia 1930 r. $^{17}$ W okresie sprawowania przez niego funkcji dowódcy batalionu (przy wydatnej pomocy z jego strony) powstało w jednostce m.in. kółko teatralne, które w okresie od 3 maja 1928 r. do 3 maja 1929 r. wystawiło 11 sztuk oraz urządziło 4 wieczorki w rocznice świąt narodowych. Powstała wtedy również orkiestra, która brała udział w obchodach różnego rodzaju świąt ${ }^{18}$.

Dla postronnego obserwatora najbardziej widoczny był udział wojsk garnizonu w obchodach świąt państwowych, kościelnych i wojskowych o charakterze ogólnopaństwowym. Można powiedzieć, że w okresie międzywojennym nie wyobrażano sobie święta 11 listopada czy dnia 3 maja bez asysty wojskowej. Z drugiej strony trzeba stwierdzić, iż dowództwo 16 Batalionu KOP „Sienkiewicze” - podobnie jak inne jednostki Wojska Polskiego - wykorzystywały te okazje do kształtowania poczucia patriotyzmu, obywatelskiej postawy, dumy z dokonań

${ }^{13}$ Latem 1929 r. do nazw jednostek i pododdziałów KOP, począwszy od strażnic po brygadę, dodano nazwę miejscowości, w jakiej stacjonowały (brygady zaś nazwę geograficzną obszaru, na którym działały). Do 1931 r. w nazwie jednostek pozostały numery. Dla ujednolicenia w tekście Autor używa określenia 16 batalion „Sienkiewicze” dla całego omawianego okresu.

${ }_{14}$ Dokument nr 11. 1925, luty [16], Warszawa, Zarzadzenie ministra spraw wojskowych gen. dyw. Władysława Sikorskiego w sprawie sformowania oddziałów KOP, [w:] O niepodległa i granice, t. IV (Korpus Ochrony Pogranicza 1924-1939. Wybór dokumentów), wstęp M. Jabłonowski, współpraca J. Prochwicz, oprac., wybór i przygotowanie do druku M. Jabłonowski, W. Janowski, B. Polak, J. Prochwicz, Warszawa-Pułtusk 2001, s. 51; Korpus Poleski 1918-1928, red. W. Wierzbicki, B. Skarzyński, J. Waszczuk, [Brześć nad Bugiem] 1928, s. 190.

15 J. Prochwicz, Korpus Ochrony Pogranicza w przededniu wojny, cz. 1 (Powstanie i przemiany organizacyjne KOP do 1939 r.), „Wojskowy Przegląd Historyczny” 1994, R. XXXIX, nr 3 (149), s. 151.

${ }^{16}$ Dz. Pers. MSWojsk. 1927, nr 24, s. 288 oraz 1932, nr 6, s. 254. W późniejszym okresie, już w stopniu pułkownika, S. Hojnowski dowodził 45 pułkiem piechoty stacjonującym w Równem, z którym w trakcie kampanii wrześniowej walczył w ramach Armii „Prusy” gen. dyw. Stefana Dęba-Biernackiego. Stanisław Hojnowski poległ w Tomaszowie Mazowieckim w nocy z 6 na 7 IX 1939 r. Szerzej na temat płk. Hojnowskiego: M. S te fań s ki, Pułkownik Stanisław Hojnowski. Próba nakreślenia życiorysu obrońcy Tomaszowa Mazowieckiego z września 1939 r., [w:] Additamenta Historica. Studia z dziejów dalekich i bliskich, red. B. Klassa, Gdańsk 2016, s. 149-159.

${ }^{17}$ Dz. Pers. MSWojsk. 1929, nr 21, s. 439.

${ }_{18}$ A. Nowak, 16 baon K.O.P. Sienkiewicze. Teatr, kino, orkiestra, „Żołnierz Polski” 1929, nr 21, s. 513. 
i przeszłości państwa polskiego. Obchodzone uroczyście święta odgrywały ważną rolę nie tylko w procesie wychowania obywatelskiego i społecznego żołnierzy, lecz także w krzewieniu patriotyzmu i propagowaniu przywiązania lokalnej ludności do państwa polskiego. Miały one swój specjalny program i szczególną oprawę, a przygotowania do nich trwały zazwyczaj kilka tygodni i były połączone z cyklem pogadanek o tradycjach bojowych danej jednostki oraz znaczeniu obchodzonych świąt. Szybko też ukształtował się ich - powtarzany rokrocznie - schemat: uroczysta msza, defilada, obiad żołnierski oraz wspólne zabawy i zawody sportowe, przy szerokim współudziale miejscowych społeczności oraz przedstawicieli władz wojskowych i państwowych.

Stan zachowania dokumentów 16 Batalionu KOP „Sienkiewicze” znajdujących się w Archiwum Straży Granicznej w Szczecinie nie pozwala na rekonstrukcję w zadowalającym stopniu jego dziejów, w tym i obchodzonych świąt. Rozkazy dzienne batalionu zachowały się dopiero od roku 1928. Ponadto, jeśli chodzi o święta religijne, ograniczono się w nich w zasadzie do złożenia życzeń przez dowódcę podległym mu oficerom i żołnierzom. W sukurs przychodziły artykuły pojawiające się w czasopiśmie „Żołnierz Polski”, które były relacjami z obchodzonych w jednostce świąt. Jednak i one nie pozwalają na całościowe ujęcie obchodów dni świątecznych z tego okresu, wiele elementów powtarzało się jednak rokrocznie, więc rekonstrukcję uroczystości można ukazać na konkretnych przykładach. W tekście omówione zostaną święta: państwowe (3 maja), wojskowe (Żołnierza Polskiego - 15 sierpnia i 11 listopada) oraz religijne (święta Wielkiej Nocy oraz Bożego Narodzenia). Nie były to oczywiście wszystkie święta jakie obchodzono, toteż przywołano również obchody dnia imienin Marszałka Józefa Piłsudskiego oraz rocznice powstania styczniowego. Osobną kwestią jest święto KOP (ustanowione rozkazem z 14 września 1936 r.) i obchodzone dnia 14 października na pamiątkę przejęciu od armii oddziałów sformowanych dla omawianej formacji. Ponieważ jednak obchodzono je dopiero od 1936 r. - w niniejszym tekście zostało ono pominięte z oczywistych względów. Należy również zaznaczyć, iż w tekście opisano obchody świąt kościelnych katolickich, bowiem w założeniu w KOP służyć mieli oficerowie, podoficerowie i szeregowi narodowości polskiej, o nieposzlakowanej opinii, ponadto w przypadku szeregowych preferowani byli umiejący czytać i pisać synowie chłopscy ${ }^{19}$. Postulat ten był jednak w zasadzie niemożliwy do zrealizowania przy ówczesnej mozaice narodowościowej II RP, toteż w jednostkach KOP służyli również przedstawiciele mniejszości $i^{20}$. Wobec tego np. w relacjach prasowych o obchodach świąt kościelnych żołnierze opisywali uroczystości katolickie, natomiast jeśli chodzi o święta prawosławne

${ }^{19}$ Dokument nr 5. 1924, październik [14], Warszawa, Instrukcja ministrów spraw wojskowych Wtadystawa Sikorskiego oraz spraw wewnętrznych Cyryla Ratajskiego o przejęciu od armii oddziatów sformowanych dla KOP, [w:] O niepodległa i granice..., s. 41.

${ }^{20}$ J. Prochwicz, op. cit., s. 149, 153. 
- ograniczano się w zasadzie do wzmiankowania zwolnień szeregowych wyznania prawosławnego na urlopy w okresie świątecznym ${ }^{21}$. Przy podawaniu wykazu świąt niekatolickich w odniesieniu do wyznania prawosławnego podawano również informację, iż żołnierze tego wyznania z terenów DOK II, III i IX mieli obchodzić święta wraz z ludnością cywilną według starego stylu (13 dni później od dat podanych w wykazie) oprócz Wielkanocy, Wniebowstąpienia i Zielonych Świątek, których daty pokrywały się z datami owych świąt podanymi w wykazie świąt wyznań niekatolickich ${ }^{22}$.

Jednym z najważniejszych świąt państwowych obchodzonych w batalionie było święto 3 maja, ustanowione z okazji uchwalenia w $1791 \mathrm{r}$. pierwszej polskiej konstytucji. W przeddzień uroczystości - wojsko urządzało uroczyste capstrzyki na ulicach miast i w garnizonach. W dniu święta oficerowie i pododdziały uczestniczyli w nabożeństwach dziękczynnych, następnie dokonywano przeglądu wojsk i urządzano defilady. Z kolei popołudniami urządzano zawody sportowe, zabawy taneczne bądź też inne atrakcje ${ }^{23}$. Nie inaczej było w Sienkiewiczach. W 1929 r. w przeddzień 3 maja odbył się uroczysty capstrzyk, natomiast w sam dzień uroczystości kompania reprezentacyjna batalionu wyruszyła do Łachwy do dowództwa 5 Brygady KOP, celem wzięcia udziału w uroczystym nabożeństwie i defiladzie, którą odbierał dowódca brygady wraz ze sztabem. Właściwe obchody w Sienkiewiczach wypadły w niedzielę 5 maja. Tego dnia kółko teatralne batalionu wystawiło trzyaktową sztukę pt. Jego Kapralska Mość, poświęconą Marszałkowi J. Piłsudskiemu, która przedstawiała epizody z jego okresu legionowego. Wykonanie przypadło do gustu licznie zgromadzonej publiczności, która nagrodziła aktorów burzą oklasków. Ponadto, niejako przy okazji święta narodowego, rocznice istnienia obchodziło również samo kółko teatralne batalionu ${ }^{24}$. Natomiast na obchody 3 maja w 1931 r. w batalionie „Sienkiewicze” składały się m.in. poświęcenie nowego krzyża postawionego i ufundowanego przez żołnierzy KOP oraz projekcja filmu pt. Mogiła nieznanego żolnierza (reż. Ryszard Ordyński - 1927). Dzień przed świętem flagi państwowe zawisły na budynkach wojskowych i cywilnych, na co wpłynęły pogadanki przeprowadzone przez oficera PW batalionu. Następnie przez wieś przeszedł uroczysty capstrzyk, który pociągnął za sobą ludność cywilną. O godzinie $20.00 \mathrm{w}$ parku koszarowym nastąpiła projekcja filmu, na którą wstęp był bezpłatny, dzięki czemu ściągnęła dużą publiczność. W trakcie

${ }^{21}$ Vide np. Rozkaz dzienny nr 2, Sienkiewicze 9 I 1931, Archiwum Straży Granicznej w Szczecinie [dalej: ASG Szczecin], KOP, Brygada „Polesie”, Batalion Graniczny „Sienkiewicze”, Rozkazy dzienne Dowództwa Batalionu Granicznego „Sienkiewicze” 1931, sygn. 183/63, k. 3.

22 Vide m.in. Rozkaz dzienny nr 2, Sienkiewicze 12 I 1932, ASG Szczecin, KOP, Brygada „Polesie”, Batalion Graniczny „Sienkiewicze”, Rozkazy dzienne Dowództwa Batalionu Granicznego „Sienkiewicze” 1932, sygn. 183/64, k. 8.

${ }^{23}$ F. Ku si a k, Życie codzienne oficerów Drugiej Rzeczypospolitej, Warszawa 1992, s. 225.

${ }^{24}$ [A.] Nowak, 16 baon K.O.P. Sienkiewicze - Uroczystość 3 maja, „Żołnierz Polski” 1929, nr 20, s. 487. 
projekcji, gdy na ekranie pokazywano szarże kawalerii, osoby po raz pierwszy w życiu oglądające film zaczęły uciekać, wróciły jednak uspokojone na swoje miejsce. W dniu święta, po pobudce, odprawiona została msza przed nowo powstałym krzyżem, a następnie pododdziały przemaszerowały przed dowódcą Brygady „Polesie”. Po wspólnym obiedzie zaś spotkano się w ogrodzie, gdzie do wieczora tańczono przy dźwiękach batalionowej orkiestry ${ }^{25}$.

Podobnie obchodzono święta wojskowe, urządzano capstrzyki, brano udział w nabożeństwach oraz organizowano zabawy. W dniu Święta Żołnierza Polskiego (15 sierpnia) w 1928 r. dowódca 16 Batalionu KOP zarządził, aby dowódcy pododdziałów dopilnowali, by w uroczystościach wzięła udział jak największa liczba mieszkańców okolicznych wsi i miasteczek. Obchody miały wywrzeć niezapomniane wrażenie i zapaść w pamięć żołnierzom i okolicznej ludności. Należało porozumieć się z przedstawicielami władzy, szkół i organizacji społecznych. Na obchody złożyły się pogadanki, odczyty i capstrzyk w przededniu święta (14 sierpnia), pobudka, podniesienie chorągwi na strażnicach i odwodach kompanii, wspólna modlitwa (ewentualnie nabożeństwo), zawody, popisy, zabawy ludowe etc. Natomiast 15 sierpnia strażnice, odwody kompanii i słupy graniczne miały być udekorowane zielenią i barwami narodowymi. W przeprowadzanych pogadankach oficerowie mieli kłaść nacisk na znaczenie zwycięstwa z roku 1920, które było osiągnięte dzięki woli i planowi Naczelnego Wodza Marszałka J. Piłsudskiego oraz dzięki wysiłkom wojska i społeczeństwa. Podkreślali, że zwycięstwo to stało się fundamentem niepodległości. Ponadto 15 sierpnia szeregowi batalionu mieli otrzymać lepszą strawę, o ile pozwolą na to posiadane środki. Ta kwestia powinna zostać rozstrzygnięta między dowódcami pododdziałów a kwatermistrzem batalionu. Na ten dzień szeregowi batalionu mieli być obstrzyżeni i ogoleni. Ewentualne fotografie i sprawozdanie z uroczystości należało dostarczyć do dowództwa batalionu do 18 sierpnia. Nad programem uroczystości czuwał komitet, składający się z 5 podoficerów (3 poruczników, starszego sierżanta i sierżanta) $)^{26}$.

Z kolei w 1931 r. obchody Święta Żołnierza w 16 Batalionie KOP odbywały się w Mikaszewiczach, gdzie staraniem lokalnego oddziału PW już 14 sierpnia udekorowano wszystkie państwowe budynki zielenią i barwami narodowymi. W dniu święta odbyła się polowa msza święta, po której kpt. Marek Hajdasz, dowódca 1 kompanii batalionu, wygłosił odczyt poświęcony osobie J. Piłsudskiego, następnie odbyła się defilada przybyłych oddziałów wojska i PW, którą przyjmował dowódca batalionu. Po zakończeniu uroczystości udano się na wspólny obiad, natomiast o godzinie 14.00 rozpoczęły się zawody sportowe, w których

${ }^{25}$ J. P i e rśc iń s ki, 16 baon „Sienkiewicze”. Polesie. 3 Maj, „Żołnierz Polski” 1931, nr 23, s. 546.

${ }^{26}$ Rozkaz dzienny nr 80, Sienkiewicze 11 VIII 1928, ASG Szczecin, KOP, Brygada „Polesie”, Batalion Graniczny „Sienkiewicze”, Rozkazy dzienne Dowództwa Batalionu z 1928, sygn. 183/60, k. 5-6. 
wzięli udział żołnierze batalionu i członkowie PW, które wygrała reprezentacja batalionu. Na koniec dnia wszyscy bawili się na zabawie, którą umilała orkiestra batalionu ${ }^{27}$.

Ale święta wojskowe to nie tylko Święto Żołnierza Polskiego - to także święto 11 listopada, obchodzone jako Dzień Niepodległości ${ }^{28}$. Dnia 10 listopada 1930 r. orkiestra batalionu w towarzystwie plutonu kompanii szkolnej koncertowała przed budynkiem szkoły powszechnej, następnie we wsi Mokrowo, na koniec zaś przed budynkiem dowództwa batalionu. Wieczorem wywieszono chorągwie w barwach narodowych. Następnego dnia, 11 listopada, o godzinie 10.00 ppłk. S. Hojnowski dokonał przeglądu kompanii szkolnej i drużyny dowódcy, następnie przyjął defiladę odbywającą się na drodze Sienkiewicze-Lenin. Ponadto dowódcy pododdziałów przed południem przeprowadzili w pododdziałach pogadanki nt. odzyskania niepodległości, a o godzinie 12.00 odbył się wspólny żołnierski obiad. Wieczorem, o godzinie $18.00 \mathrm{w}$ świetlicy kompanii szkolnej odbyła się akademia, na program której złożyły się koncert orkiestry batalionu, odczyt okolicznościowy, występy słowno-muzyczne dzieci ze szkoły powszechnej w Sienkiewiczach oraz występ chóru batalionowego. Na „wieczorku” gościł dowódca batalionu, oficerowie z rodzinami oraz ludność i młodzież szkolna ${ }^{29}$.

Święta państwowe i wojskowe nie były jedynymi, które obchodzono w wojsku. Pewne elementy religijne, jak już wspomniano, występowały również przy okazji innych świąt. Wojsko zobowiązane było także do uczestniczenia w świętach wyznania rzymskokatolickiego, takich jak Wielkanoc czy Boże Ciało. Relacje z Kościołem zacieśniał fakt, iż przez 123 lata zaborów podtrzymywał on polskość. Udział w uroczystościach kościelnych umacniał postawy patriotyczne, integrował wewnętrznie oraz podnosił poziom moralny kadry ${ }^{30}$.

W Kościele katolickim do największych świąt należą Boże Narodzenie i Wielkanoc. $\mathrm{Z}$ zachowanego i przeanalizowanego materiału wynika, iż w przypadku Bożego Narodzenia dowódca batalionu najczęściej przekazywał życzenia świąteczne żołnierzom poprzez rozkazy dzienne, łącznie z życzeniami na Nowy Rok ${ }^{31}$. Podobnie rzecz wyglądała na Wielkanoc ${ }^{32}$. Dzięki relacji zamieszczonej w czasopiśmie „Żołnierz Polski” możemy dowiedzieć się, jak wyglądały wielkanocne

27 [A.] S z c zep ańs k i, 16 baon K.O.P. Święto Żotnierza, „Żołnierz Polski” 1931, nr 36, s. 814.

28 Jako święto narodowe 11 listopada został ustanowiony dopiero w $1937 \mathrm{r}$.

${ }^{29}$ W. J arczyń ski, 16 baon „Sienkiewicze” Polesie, „Żołnierz Polski” 1930, nr 48, s. 1188.

${ }^{30}$ F. Ku siak, op. cit., s. 14, 20.

${ }^{31}$ Na przykład, Rozkaz dzienny nr 94, Sienkiewicze 22 XII 1931, ASG Szczecin, KOP, Brygada „Polesie”, Batalion Graniczny „Sienkiewicze”, Rozkazy dzienne Dowództwa Batalionu Granicznego „Sienkiewicze” 1931, sygn. 183/63, k. 141.

${ }^{32}$ Vide m.in. Rozkaz dzienny nr 29, Sienkiewicze 16 IV 1930 r., ASG Szczecin, KOP, Brygada „Polesie”, Batalion Graniczny „Sienkiewicze”, Rozkazy dzienne Dowództwa Batalionu Granicznego „Sienkiewicze” 1930, sygn. 183/62, k. 37; Rozkaz dzienny nr 22, Sienkiewicze 24 III 1932 r., ASG Szczecin, KOP, Brygada „Polesie”, Batalion Graniczny „Sienkiewicze”, Rozkazy dzienne Dowództwa Batalionu Granicznego „Sienkiewicze” 1932, sygn. 183/64, k. 84. 
obchody w batalionie w 1929 r. W owym roku - w Wielką Niedzielę, w świetlicy batalionu, spotkali się żołnierze, którzy nie udali się na świąteczne urlopy, na wspólnym obiedzie, który zaszczycił dowódca batalionu z oficerami kompanii szkolnej i sztabu batalionu. Po złożeniu życzeń, mjr S. Hojnowski podzielił się z żołnierzami tradycyjnym jajkiem święconym i zasiadł z nimi do wspólnego obiadu. Pozwoliło to żołnierzom choć na chwilę zapomnieć o codzienności i o tym, że nie spędzają świąt $\mathrm{w}$ rodzinnym gronie $^{33}$.

W kalendarzu świąt i uroczystości obchodzonych w 16 Batalionie nie mogło zabraknąć również dnia 19 marca, czyli imienin Marszałka J. Piłsudskiego. Od dnia odzyskania niepodległości, z wyjątkiem lat 1924-1926, miały one jednakowy przebieg. W przededniu dekorowano koszary, urządzano capstrzyk oraz urządzano pogadanki, akademie i spektakle. Natomiast 19 marca rano odbywała się uroczysta msza święta, następnie generał lub najwyższy rangą oficer odbierali defiladę, potem następowało przyjęcie przez władze cywilne i wojskowe życzeń dla Marszałka m.in. od stowarzyszeń, szkół etc. Część oficjalną kończył wspólny żołnierski obiad, w trakcie którego jeden $\mathrm{z}$ oficerów wspominał życie i czyny J. Piłsudskiego. Po południu odbywały się akademie, zawody sportowe, swoje umiejętności prezentowały chóry i orkiestry żołnierskie, śpiewano i deklamowano utwory sławiące Marszałka J. Piłsudskiego ${ }^{34}$. W Sienkiewiczach w 1930 r. święto to rozpoczęło się 18 marca przejściem plutonu kompanii szkolnej i orkiestry batalionu przez Sienkiewicze i Mokrów z pochodniami i lampionami. Następnego dnia rano orkiestra ponownie przeszła przez obie wioski, grając przy tym utwory patriotyczne. O godzinie 10.00 odbyły się pogadanki okolicznościowe dotyczące życia i działalności Józefa Piłsudskiego, z kolei dwie godziny później żołnierze spotkali się na wspólnym obiedzie w świetlicy kompanii szkolnej, gdzie na honorowym miejscu ustawiono popiersie Marszałka Polski. Kolejne uroczystości miały miejsce wieczorem 19 marca. Na początek orkiestra batalionu odegrała „Pierwszą Brygadę", następnie głos zabrał kierownik szkoły powszechnej z Sienkiewicz. Potem nastąpiła deklamacja dwóch utworów („Raport” i „K.O.P.”) przez szeregowych kompanii szkolnej, po czym orkiestra batalionowa wykonała utwory patriotyczne. I tym razem na ,wieczorku” obecny był ppłk S. Hojnowski, oficerowie z rodzinami, szeregowi garnizonu Sienkiewicze oraz ludność i młodzież szkolna, która licznie się stawiła ${ }^{35}$.

Natomiast w roku 1932 już na kilka tygodni przed datą imienin Marszałka J. Piłsudskiego kółko teatralne batalionu rozpoczęło próby sztuki pt. Więzień magdeburski. 19 marca 1932 r. orkiestra batalionowa przeszła przez Sienkiewicze i Mokrowo wraz z jednym plutonem batalionu i odegrała uroczystą pobudkę. O godzinie 9.00 żołnierze wysłuchali pogadanek na temat J. Piłsudskiego, zaś

\footnotetext{
${ }^{33}$ [A.] N o w a k, 16 baon K.O.P. - Święta wielkanocne, „Żołnierz Polski” 1929, nr 18, s. 437.

${ }^{34}$ F. Kusiak, op. cit., s. 231.

35 W. Jarczýn s ki, 16 baon „Sienkiewicze” Polesie, „Żołnierz Polski” 1930, nr 14, s. 341.
} 
w południe spotkali się na wspólnym obiedzie w świetlicy kompanii odwodowej, na którym byli obecni dowódca batalionu z małżonką, dowódcy pododdziałów i orkiestra. Wieczorem odbyła się akademia, na której swoje umiejętności mogła zaprezentować orkiestra batalionu i młodzież szkolna oraz odegrano wspomnianą sztukę pt. Więzień magdeburski ${ }^{36}$.

Oprócz dnia imienin Marszałka J. Piłsudskiego obchodzono również np. rocznice powstania styczniowego, którego weterani w II Rzeczypospolitej cieszyli się niezwykłą estymą i szacunkiem. 21 stycznia 1929 r. urządzono w batalionie uroczystą akademię, której program, jak na warunki Sienkiewicz, był bogaty. W jej trakcie wystąpiła orkiestra 5 Brygady KOP oraz chór batalionowy. Odegrano również jednoaktową sztukę pt. Korale Marysi i Kasi oraz odśpiewano wiele żołnierskich piosenek. Całość wywarła duże wrażenie na obecnych na obchodach, czyli na korpusie oficerskim i podoficerskim oraz szeregowcach batalionu i miejscowej ludności ${ }^{37}$.

Przywołane tutaj przykłady obchodów poszczególnych świąt nie miały tylko charakteru wspominkowego czy rozrywkowego. Miały one oddziaływać na ludność pogranicza, pokazując m.in., czym jest Polska oraz nieść kaganiec oświaty na kresy. Warto zwrócić uwagę, że KOP realizował swoją misję na terenach kresowych, na których ludność polska stanowiła mniejszość. Ponadto garnizony kresowe, w których stacjonował KOP, znajdowały się na mniej rozwiniętych i zurbanizowanych obszarach niż te $\mathrm{z}$ innych rejonów kraju. Trudno dziś jednoznacznie ocenić, jak dalece działania prowadzone przez dowództwo i żołnierzy 16 Batalionu KOP „Sienkiewicze” wpłynęły na ludność pogranicza, choć częściowo odpowiedzią na to pytanie jest formułka, którą zawierały niektóre z artykułów relacjonujących działalność batalionu. Dotyczyła ona faktu, że praca kulturalno-oświatowa postępowała wolno, ale stale, toteż okoliczni mieszkańcy odwiedzali kino i wieczorki okolicznościowe urządzane przez KOP coraz chętniej i częściej. Na pewno praca „kopistów” dodawała kolorytu życiu mieszkańców pogranicza oraz przynosiła im wiele nowinek, takich jak np. kino. Nie byli oni jednak w tej pracy osamotnieni, wspomagały ich w tym dziele władze lokalne oraz księża. Na zakończenie można stwierdzić, iż organizowane z dużym nakładem środków obchody świąt państwowych i wojskowych miały ogromne znaczenie dla wychowania obywatelskiego i patriotycznego żołnierzy, gdyż przypominały im doniosłe fakty, nie tylko z historii własnej jednostki, lecz także historii Polski, uczyły szacunku dla symboli wojskowych oraz pomagały zbliżyć żołnierzy do własnego społeczeństwa. Trudno jednak stwierdzić, czy obchody te przyniosły zamierzony efekt propagandowy w odniesieniu do lokalnej społeczności zamieszkującej wschodnie pogranicze kraju.

${ }^{36}$ I d e m, Baon K.O.P. „Sienkiewicze”. 19 marca, „Żołnierz Polski” 1932, nr 17, s. 336.

${ }^{37}$ A. Nowak, 16 Baon K.O.P. - Obchód powstania styczniowego, „Żołnierz Polski” 1929, nr 7, s. 158. 


\section{Bibliografia}

\section{ŹRÓDŁA ARCHIWALNE}

Archiwum Straży Granicznej w Szczecinie [ASG Szczecin]

Korpus Ochrony Pogranicza, Brygada „Polesie”, 16 Batalion Graniczny „Sienkiewicze”, Rozkazy dzienne Dowództwa 16 Batalionu Granicznego „Sienkiewicze”, sygn. 183/60; 183/63; 183/64.

\section{ŹRÓDEA DRUKOWANE}

Drugi powszechny spis ludności z dn. 9.XII.1931 r. Mieszkania i gospodarstwa domowe. Ludność. Stosunki zawodowe. Województwo poleskie, Warszawa 1938.

Dziennik Ustaw 1928, nr 46.

Dzienniki Personalne Ministerstwa Spraw Wojskowych: nr 24 z 1927 r.; nr 21 z 1929 r.; nr 6 z 1932 r.

Korpus Poleski 1918-1928, red. W. Wierzbicki, B. Skarzyński, J. Waszczuk, [Brześć nad Bugiem] 1928.

Nasz dorobek pracy kulturalno-oświatowej, [w:] Korpus Ochrony Pogranicza. W trzecia rocznice objęcia stużby na granicach Rzeczypospolitej 1926-1927, red. F. Jamka-Koperski, Warszawa 1927, s. 14-16.

Pierwszy powszechny spis Rzeczypospolitej Polskiej z dnia 30 września 1921 r. Mieszkania. Ludność. Stosunki zawodowe. Województwo poleskie, Warszawa 1926.

Skorowidz miejscowości Rzeczypospolitej Polskiej opracowany na podstawie wyników Pierwszego Powszechnego Spisu Ludności z dn. 30 września 1921 r. i innych źródeł urzędowych, t. VIII (Województwo Poleskie), Warszawa 1924.

Skorowidz miejscowości Rzeczypospolitej Polskiej z oznaczeniem terytorjalnie im właściwych władz i urzędów oraz urządzeń komunikacyjnych, red. T. Bystrzycki, Przemyśl-Warszawa [b.d.w].

\section{Prasa}

„Żołnierz Polski” 1929, 1930, 1931, 1932.

\section{OPRACOWANia}

Kusiak F., Życie codzienne oficerów Drugiej Rzeczypospolitej, Warszawa 1992.

O niepodległa i granice, t. IV (Korpus Ochrony Pogranicza 1924-1939. Wybór dokumentów), wstęp M. Jabłonowski, współpraca J. Prochwicz, oprac., wybór i przygotowanie do druku M. Jabłonowski, W. Janowski, B. Polak, J. Prochwicz, Warszawa-Pułtusk 2001.

Prochwicz J., Korpus Ochrony Pogranicza w przededniu wojny, cz. 1 (Powstanie i przemiany organizacyjne KOP do 1939 r.), „Wojskowy Przegląd Historyczny” 1994, R. XXXIX, nr 3 (149), s. $148-160$.

Rzepkowski A., Spisy ludności na ziemiach polskich w latach 1789-1939, „Przegląd Nauk Historycznych" 2005, $\mathrm{nr} 2$ (8), s. 101-123.

Stefański M., Pułkownik Stanisław Hojnowski. Próba nakreślenia życiorysu obrońcy Tomaszowa Mazowieckiego z września 1939 r. [w:] Additamenta Historica. Studia z dziejów dalekich i bliskich, red. B. Klassa, Gdańsk 2016, s. 149-159.

Śleszyński W., Województwo poleskie, Kraków 2014. 


\section{MAREK STEFAŃSKI}

\section{Public, military and church holidays in Frontier Defence Corps on an example $16^{\text {th }}$ Battalion ,Sienkiewicze” between 1927-1932}

\footnotetext{
The article describes how chief and soldiers from $16^{\text {th }}$ Battalion ,Sienkiewicze”, unit of Frontier Defence Corps, celebrating public, military and church holidays beetwen 1927-1932. The period indicated in the title coincides with the command of the battalion by major / lieutenant colonel Stanisław Hojnowski, officer of the Polish Army, later was a chief of the $45^{\text {th }}$ Infantry Regiment. In the text author show how in $16^{\text {th }}$ battalion celebrating Easter, Christmas, Polish Soldier's Day, November 11, name day of Marshal Piłsudski etc. In the Eastern Borderlands, where the Poles was a minority, holidays wasn't only fun and rest, them was have an important propaganda role. The celebrations with army and public authorities was integrated population of the eastern borders with Poland.
}

Keywords: Frontier Defence Corps, $16^{\text {th }}$ Battalion „Sienkiewicze”, Stanisław Hojnowski, $11^{\text {th }}$ November, $15^{\text {th }}$ August, Christmas, name-day of Marshal Piłsudski, history of Polesie, Polesie voivodeship. 